\title{
IS GREEN MARKETING AN OXYMORON? A HOLISTIC VIEWPOINT
}

\section{Julen Izagirre-Olaizola}

\author{
University of the Basque Country
}

\begin{abstract}
This study sets out to examine the concept of green marketing from a broadbased perspective, focusing particularly on how it may contribute to the adaptation or transformation of the dominant social paradigm in which environmental aspects have hitherto not been considered in economic relationships. A multi-theoretical, interdisciplinary approach is used, because the way in which businesses manage the environmental factor is not an isolated issue constrained only to the internal running of each organisation but rather a general issue that needs a general, integration-based outlook and a long-term approach. Bearing in mind that sustainable development and the protection of the environment are complex, multifaceted issues, particularly as regards their links to consumer activities and environmental awareness, we believe that it is particularly important to clarify the role played by green marketing from a holistic viewpoint, emphasising the need for it to be applied across the board by firms.
\end{abstract}

Keywords: marketing, sustainability, consumption, macromarketing, critical perspective, holistic viewpoint

DOI: https//doi.org/10.3176/tr.2021.3.04

Received 11 November 2020, accepted 9 March 2021, printed and available online 10 September 2021 


\section{Introduction: the emergence of a sub-discipline}

Many authors have identified high levels of consumerism in the most highly developed Western societies (and increasingly also in recently industrialised countries) as one of the leading causes of the deterioration of the environment (Connolly and Prothero 2003, Pereira and Chatzidakis 2011, Ertekin and Atik 2015, Barbarossa and De Pelsmacker 2016, Yakobovitch and Grinstein 2016). It can be argued that marketing merely responds to and helps to meet the needs of consumers by creating value with that purpose, but those responsible for the discipline have never stood out for encouraging consumers to adopt a simple lifestyle (O'Shaughnessy and O'Shaughnessy 2002). Even in academic circles, studies that suggest how the knowledge generated can be used to foster higher levels of consumerism (Pereira and Chatzidakis 2011) can be found in far greater numbers than those which focus on de-marketing and on analysing the limits of consumerism (Connolly and Prothero 2003, Peattie and Peattie 2009). That being said, there has been increasing criticism of marketing and its role in society (Tadajewski and Brownlie 2008, Nair and Little 2016), with pioneering contributions in this area dating back over 40 years (Kotler 1971).

The way in which the ethos of marketing is understood is not unconnected to changes in society as a whole. Indeed, one of the major trends in the discipline in the past few decades has been the emergence of a social concept of marketing (Ottman 1993, Vicente 2000). The spread of a more sensitive attitude towards a range of social and environmental problems has led marketing to extend its field of action to society as a whole, going beyond merely meeting the needs of consumers.

Its development has been so marked that even the general definition of marketing was changed in 2007 to incorporate a social element. Thus, the definition published in July 2013 by the American Marketing Association reads as follows: "Marketing is the activity, set of institutions, and processes for creating, communicating, delivering, and exchanging offerings that have value for customers, clients, partners, and society at large." This trend means that the discipline has accepted a number of points that valorise its social aspects, with relations between businesses and consumers understood to take place in a context where the social orientation of marketing must not be obviated.

The appearance of greater sensitivity in regard to the protection of the environment, social justice and caring for health has resulted in the emergence of new approaches to marketing. Concern for environmental problems has increased in the past few decades, and this heightened awareness among a large proportion of people in the most advanced societies has led firms to turn to new ways of behaving in business (Peattie and Crane 2005, Moravcikova et al. 2017).

Guided by a feeling of responsibility for their surroundings or by the appearance of new business opportunities, many organisations have begun to shift towards activities conducive to more environmentally friendly management. In this way, the paradox perspective on corporate sustainability accommodates interrelated yet conflicting economic, environmental, and social concerns with the objective of 
achieving superior business contributions to sustainable development (Hahn et al. 2018). Rather than seeking to align environmental and social aspects with financial performance to eliminate tensions, a paradox perspective fosters strategies that accept tensions and attend to different sustainability objectives simultaneously, even if they are conflicting (Carollo and Guerci 2018, Hahn et al. 2018).

In the wake of this increase in the number of people who are beginning to emphasise environmental concerns in their behaviour patterns as consumers, green marketing emerged as a variant of marketing that could be used to help firms make use of the new opportunities that seemed to be arising (Durmaz and Zengin 2011).

Green marketing seeks to use the various tools available to firms to meet the needs of consumers who are demanding more and more environmental friendliness from products, brands and firms.

However, initial optimism as regards the growth potential of the environmental product market has not been borne out. In spite of an apparently favourable trend, growth in the consumption of environmentally friendly products has all but stagnated (Bonini and Openheim 2008). That being said, there is still a potentially large market, so a re-launching of the sector may be expected (Cronin et al. 2011, Chen and Chang 2013, Lu et al. 2015, Nair 2015).

With a view to stimulating the environmental product market, academics from all around the world have focused since the 1970s on learning the characteristics of those consumers who show increasing concern for the environment and are willing to change their behaviour in order to help protect it (Chamorro et al. 2009).

It was this factoring in of the environment as a basic variable in the way in which two-way relationships are seen by business organisations that led to the emergence of green marketing. Its impact on business management can be attributed to increasing awareness of environmental issues on the part of society, with that concern being passed on to a greater or lesser extent to the world of business (Estes 2010). From this viewpoint any organisation that operates within a society can be understood as having a responsibility to that society. Moreover, the fact that more and more consumers are coming to see environmental issues as important in the products that they buy means that a new business opportunity exists in responding to that heightened awareness (Durmaz and Zengin 2011).

To examine the concept of green marketing the first step is to look briefly at the philosophy of marketing and analyse how it evolved towards the more social outlook that has emerged in recent times. From that viewpoint, the sub-discipline of green marketing posits that businesses must change the way in which they handle the use of natural and environmental resources. This change in approach calls for a gradual transformation in conventional entrepreneurial culture towards advanced social and environmental management Ludevid, 2000, Kang et al. 2016). In other words, the conventional approach in which business operations were regarded as unconnected with their surroundings has become obsolete. As a result, organisations need to factor sustainability criteria into their management and marketing decisions and make responsible use of natural resources.

This has led on the one hand to the emergence of concepts such as social 
marketing ${ }^{1}$, which extends beyond the area of entrepreneurial operations/profitmaking. Along similar lines, concepts such as 'macro-marketing' and 'megamarketing' have emerged, which consider how the needs of society can be met as a whole rather than on an individual basis and include both the process of marketing in general and the mechanisms attached to the organisations that handle it (Calomarde 2000). There is also 'de-marketing', which seeks to reduce demand for products and vital resources that may run out due to excessive consumption (Peattie and Peattie 2009, Santesmases 2012).

In practice, initiatives concerned with protecting the environment have come to account for a large proportion of the activities classed as corporate social responsibility (Kang et al. 2016) and have become one of the essential bases for the development of the concept of green marketing. In this regard, numerous authors
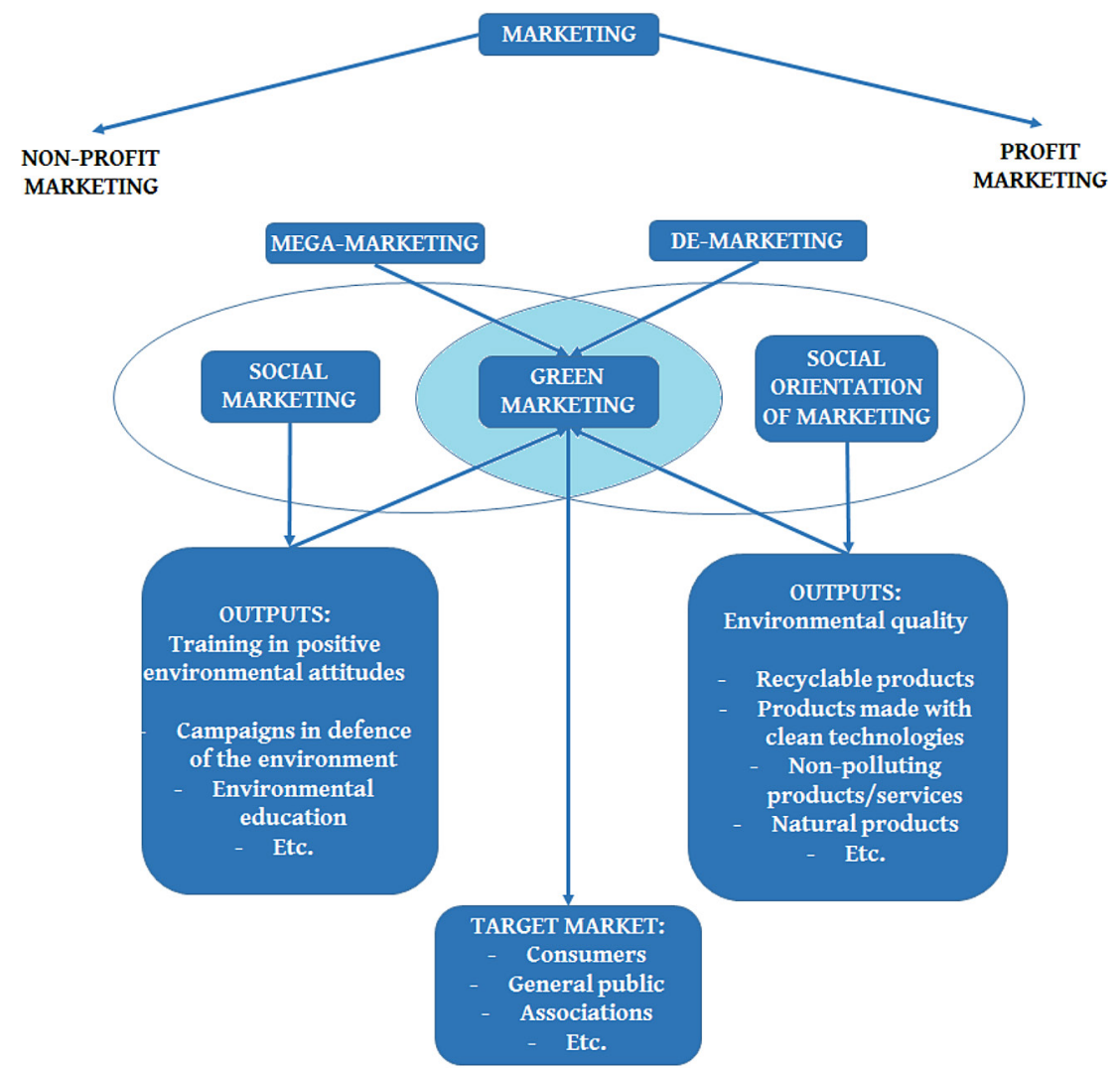

Figure 1. Location of green marketing within the conceptual framework of marketing. Source: Vicente 2000.

1 Defined as a particular part or aspect of non-corporate marketing that seeks to encourage and foster the acceptance of ideas or social behaviour patterns that are considered as beneficial to society as a whole, or to halt or discourage ideas or behaviour patterns considered as harmful (Santesmases 2012). 
have cited environmental issues as one of the fundamental factors in corporate social responsibility (Kang et al. 2016), and perhaps even as number one in order of importance among the social issues that must be taken into account by businesses nowadays (Donaldson and Preston 1995). This is because of the challenges and opportunities provided by the management of these issues (Harvey and Schaefer 2001). Although the concept was first posited earlier, it is over the past 40 years that it has developed substantially (Szocs 2011).

However, a green marketing orientation needs to take a macro-marketing perspective that includes the analysis of producers and consumers and takes account of the multifaceted nature of consumer practices. That requires a critical analysis of the role of marketing in regard to consumption and sustainability (Kilbourne and Beckmann 1998). This in turn means reflecting on whether the dominant social paradigm in developed Western countries is a valid one. Accordingly, doubt is cast on hitherto unquestionable issues such as the possibility of attaining continuous, unlimited economic growth, the limited need for government intervention in the economy and the ability of technology to prevent the destruction of the environment (Pereira and Chatzidakis 2011).

\section{From indiscriminate consumerism to environmental idealism: is green commercialism possible?}

\subsection{Questioning the dominant social paradigm}

Up to a few years ago the focus of analysis in matters of the environment in business was mainly on the supply side, covering such topics as technology and eco-innovation, business opportunities in sustainable production, links between firms and suppliers and environmental actors in general (Connolly and Prothero 2003). More recently there have been a great many studies at both domestic and international levels (with something of a time lag in the former case) focused on analysing environmentally friendly consumers, seeking to draw up profiles and set out their characteristics in terms of attitudes, motivations, behaviour patterns, etc., i.e. studies seeking to learn more about the demand side (Chamorro et al. 2009, Durmaz and Zengin 2011, Szocs 2011). However, few authors have investigated green marketing from a macro-marketing viewpoint covering its role in society, its links with other areas and, in short, the social conditions that have given rise to its emergence as a discipline and the role that it is to play in redirecting production and consumption habits in the most highly developed societies (Kilbourne and Beckmann 1998, Connolly and Prothero 2003, Chamorro et al. 2009, Prothero et al. 2010).

Most of the authors who have reviewed the main body of literature on green marketing agree that there have been two main waves of studies in the field: the first dating from the early 1970s and the second from the 1990s (with the latter continuing to some extent up to the present) (Chamorro et al. 2009, Prothero et al. 2010, Durmaz and Zengin 2011, Szocs 2011). Although the earliest high-impact studies covered macro-marketing issues, the wave of studies from the 1970s gradually turned towards 
micro-issues, with interest becoming focused on more specific, localised analyses in the past few decades (Szocs 2011).

This means that from a marketing perspective there has been hardly any overall analysis of the role of consumption and its impact on the environment, with consumption being understood as a fundamental element of what is known as the dominant social paradigm ${ }^{2}$. It can be argued that the patterns of consumer behaviour in a given society entail moral aspects related (Caruana 2007, Yakobovitch and Grinstein 2016), in this case, with the environment (Kilbourne 1995, Peattie and Peattie 2009, Prothero et al. 2010, Pereira and Chatzidakis 2011). Changes in the importance with which environmental problems are regarded fit into a transition from an anthropocentric paradigm based on the existence of a clear separation between human beings and the rest of nature to an eco-centric paradigm that values nature in itself, independently of the benefits that it may provide for humans (Carrete et al. 2012).

Connolly and Prothero (2003) assert that there has been a continued failure to explore the discourse that perpetuates the environmental crisis. The fact is that consumption is linked to deterioration of the environment, and marketing plays a core role in that link in spite of the fact that consumers often fail to see the connection (Pereira and Chatzidakis 2011). It is therefore necessary to draw up an analysis based on macro-marketing that covers the phenomenon in a holistic fashion and incorporates other areas of knowledge such as sociology, anthropology, ecology and philosophy. Thus, Bauman (2007) indicates that consumption is the new focal point of an individualised society, which turns it into its highest expression of selfrealisation, in what the author refers to as the replacement of the work ethic by an 'aesthetic of consumption'.

Accordingly, the promotion of hedonistic attitude to consumption, associating it with values such as happiness, good living and quality-of-life, is conducive to and actively encourages overconsumption (O'Shaugnessy and O'Shaughnessy 2002, Brosius et al. 2013). In this consumer society the symbolic value of products and the meanings that they entail explain the motivations of consumers in purchasing them to an extent that goes beyond their useful value (Connolly and Prothero 2003, Pereira and Chatzidakis 2011). It can be argued that marketing is oriented towards meeting the needs of consumers, who decide how to behave on the basis of their own sovereign free will (Shankar et al. 2006), but such arguments ignore the fact that consumers do not always act on the basis of sufficient, suitable information concerning consumption or indeed with the needs of future generations in mind (Peattie 1999, Pereira and Chatzidakis 2011).

Concurrently with the emergence of increasing concern for the environment and environmental problems, doubt has been cast on habits and patterns of consumption in advanced societies. These critical voices consider consumption and its harmful consequences from various points of view and stress their potentially negative effects on society (Roberts 2005, Bauman 2007, Brosius et al. 2013, Chatzidakis and Lee 2013, Gollnhofer 2017).

2 Milbraith (1984) defines the dominant social paradigm as 'a society's dominant belief structure that organises the way that people perceive and interpret the functioning of the world around them'. 
One such critical argument is concerned with the negative impact that consumer habits and levels worldwide (but particularly in the Western/developed world) have on the environment. Thus, voices have begun to be heard that hold that the current levels of consumption, especially those in industrialised countries, are unsustainable, because too many natural resources are being used up and too great a burden is being placed on ecosystems by the waste produced. It is also assumed that the levels of consumption found in 'developed' countries cannot be extrapolated or extended to the entire population of the world, so from this viewpoint it is necessary for us to learn to live, work and consume sustainably (Brosius et al. 2013). In other words, exponential population growth and uncontrolled exploitation of resources show that the current model of consumption is unsustainable.

The 'ecological footprint', a concept developed by Wackernagel and Rees in 1998 , is frequently used as an indicator for measuring the impact of the consumption of resources and energy and the production of emissions. It is defined as 'the area of productive land and water ecosystems (crop-land, pastures, woodland and aquatic ecosystems) required to produce the resources that the population consumes and assimilate the wastes that the population produces, wherever on Earth the land and water is located' (Wackernagel and Rees 1998, p. 51). At our current level of resource consumption worldwide, humanity is using the equivalent of the capacity of 1.6 planets per year, i.e. the earth needs a year and seven months to regenerate what is consumed in each year (Global Footprint Network 2016).

As a result, there have been more and more calls for changes in the dominant patterns of consumption as the only possible way of moving towards more sustainable development (Cherrier 2010, Lee et al. 2011).

Linz (2007) indicates that the search for sustainability must be pursued along three paths (all of which are essential and inseparable from one another): efficiency (better use of materials and energy), coherence (the use of technologies compatible with nature that do not destroy ecosystems) and sufficiency (seeking to reduce the consumption of resources by lowering the demand for goods). One of the numerous schools of thought that support this view is based on seeking a type of consumption that does not harm the environmental balance: the consumption of environmentally friendly products. These so-called 'eco-products' seek to reduce the environmental impacts associated with consumption by applying criteria of compatibility with current limits, greater respect for the environment and, as a result, greater benefits for society.

\subsection{Marketing and environmental friendliness: can we have both?}

There is broad agreement that consumer activities (in general) have been a cornerstone of industrial progress in the past few decades and are thus inextricably linked to environmental challenges such as the depletion of certain natural resources, reductions in biodiversity and global warming (Beck 1998, Caruana 2007). Consumerism and market operations have instilled in human beings a desire for more and more consumer goods, which has undermined the state of the environment (Prothero and Fitchett 2000). 
Many authors coincide in highlighting that there has been a significant change in the mentality of the most advanced societies in regard to the need to protect the environment, and the importance of doing so (Dunlap and Van Liere 1986, Estes 2010, Pickett-Baker and Ozaki 2008, Saari et al. 2018). However, there is less agreement concerning the extent of the change of perspective required (Naderi and Strutton 2015). For some authors the shift towards a more environmentally-friendly paradigm must necessarily involve a break with the dominant social paradigm (Clark 1990), while others argue that it is more realistic to expect the environmental viewpoint to become integrated into the dominant paradigm, thus giving rise to a discourse that is modified but in which the existing rules of the game are maintained (Kilbourne 1995, Prothero et al. 2010): 'if you can't beat them join them', in the words of Prothero and Fitchett (2000).

Some authors believe that environmental challenges can be overcome within the framework of the dominant social paradigm of capitalism (Prothero and Fitchett 2000, Prothero et al. 2010). They argue that from a mercantilist/materialistic viewpoint, progress can be made by seeking out and implementing methods to ensure more environmentally friendly packaging and distribution channels, raw materials with less impact on the environment and less environmentally harmful communication strategies. However, some advocate going further and abandoning the materialistic approach of mercantilism, casting doubt also on two other levels: production as a whole and sustainable consumption. There is a belief that capitalism does not necessarily have to be linked to the exploitation of the environment, provided that those who believe in the advantages of environmental friendliness manage to popularise their message and convey it to a broader audience (Prothero and Fitchett 2000). This would make possible to move towards more environmentally friendly consumer behaviour by incorporating environmentally-sound goods and services into existing trends, tastes and fashions (Ger 1999, Barbarossa et al. 2015).

Supporters of this approach do not deny the importance of the acquisition and consumption of products in building social status and social identity (Varey 2010, Moons and De Pelmacker 2012). They believe that these systems can be changed without abandoning them completely (Prothero et al. 2010), to the extent that materialism and wealth are positively correlated with the dominant social paradigm but are not a 'natural', non-negotiable condition (Ger and Belk 1995).

There is however agreement that merely by advocating a limitation of levels of consumption one is going against the ideas prevalent in marketing as a discipline (Varey, 2010, Pereira and Chatzidakis 2011). The current tendency of mainstream marketing to ignore the debate on reducing consumption is evidence that it does not fit comfortably into accepted marketing theory and practice (Peattie and Peattie 2009). Marketing is a key tool for sustaining lifestyles based on consumerism, so green marketing is unlikely to be a valid tool for anything other than selling certain types of product labelled as environmentally friendly, without addressing the root of the environmental problem. In this case the concept of green marketing itself can be seen as an oxymoron or contradiction in terms, to the extent that it can be argued that the only really environmentally friendly consumption is that which does not 
take place at all. However, marketing is seen to a greater or lesser extent as a tool for fostering higher levels of consumption (Pereira and Chatzidakis 2011), so only demarketing, which is intended to discourage consumption, would be capable of producing valid work aimed at effectively protecting the environment. If institutions, including disciplines and business schools, remain wedded to assumptions regarding the compatibility between the environment and economic growth and acceptance of market forces then the development of alternative perspectives on sustainability remains highly problematic (Kemper et al. 2019).

But these views do not contradict each other: they can actually be seen as mutually complementary. A pragmatic viewpoint recognises the need to identify and go to the root of the environmental problem, and assumes that even though partial, environmentally friendly commercial strategies have not managed to do this on their own they are a useful, and indeed necessary first step towards achieving substantial progress (Kilbourne 1995).

Similarly, social marketing has traditionally used the tools of commercial marketing in a relatively uncritical fashion (Peattie and Peattie 2009). But in the context of anti-consumerism the way in which products are marketed (in the context of a refusal to consume certain products) can lead to confusion. For that reason, Peattie and Peattie (2009) propose a re-drawing of the traditional '4 P's' of the marketing mix to redirect social marketing towards the concept of demarketing, replacing product by proposals, place by accessibility, price by cost of participation and promotion by social communication.

\section{Discussion: the need to tackle green marketing via an all-round approach}

\subsection{A Multi-disciplinary study area}

The study of environmental problems is a complex matter, given that it entails many different disciplines and requires a systemic approach (Bertalanffy 1976, Starik and Rands 1995, Tencati and Pogutz 2015). We therefore believe that a multitheoretical, interdisciplinary approach needs to be used, because the way in which businesses manage the environmental factor is not an isolated issue constrained only to the internal running of each organisation but rather a general issue that needs a general, integration-based outlook and a long-term approach. The concept of green marketing must therefore be approached holistically. In other words, up to now the commercial strategies applied by firms have merely presented certain specific aspects of their business strategies as 'environmentally friendly' (e.g. improvements in packaging, reductions in the use of certain types of material, etc), but have omitted a number of other aspects. If green marketing is to earn a significant place for itself and even modify some of the basic operational parameters of the production/consumption system, then it must undoubtedly opt for integration-based actions. It must cover the whole of the production and consumption process in both its organisational aspects and its consumption/post-consumption activities, taking into account issues such as sustainable consumption and the safe disposal/recovery 
of products and waste (Durmaz and Zengin 2011). In its broadest sense, green marketing must acknowledge the intrinsic value of nature and focus its attention on sustainability, even over and above economic efficiency (Kilbourne and Beckmann 1998, Pereira and Chatzidakis 2011). However, firms often tend to compartmentalise green marketing, and their failure to adopt a holistic view leaves them continually open to accusations of hypocrisy (Peattie and Crane 2005).

Only through an integration-based view (some authors speak in terms of a break and others of adaptation) is it possible to reach out to a target audience that is increasingly interested in protecting the environment without giving rise to mistrust and rejection (Dobin 2009, Parguel et al. 2011, Soler 2012). Indeed, from the viewpoint of the consumer, sustainable consumption entails far-reaching psychological and sociological changes (Ottman 1993). The literature on the environment suggests that environmentally friendly strategies based on a single issue prove insufficient, because the environment is a complex, multi-dimensional concept (Kilbourne 1995, Saari et al. 2018). It should come as no surprise that numerous opportunities for progress towards sustainability because of poorly thought through green marketing (Peattie and Crane 2005). The nature of the environmental problem means that consumers with high levels of awareness, who make up the target group most loyal to practices of this type, call on firms to provide more than just technical solutions: they look unfavourably on inconsistencies between environmentally friendly positions on some issues and business strategies that fail to take the environment into account as a whole (Kilbourne 1995).

The reasons that lead organisations to undertake environmentally friendly strategies are many and varied (Prothero and Fitchett 2000, Cronin et al. 2011). Many firms have attempted to take advantage of the increasing importance of the environmental factor in purchasing processes by adopting partial strategies, but these sometimes lack credibility (Kilbourne 1995, Carrete et al. 2012, Chen and Chang 2013, Nyilasy et al. 2014, Vitell 2015). On many other occasions, organisations have sought to improve their image by attempting what is known as 'greenwashing' (Dobin 2009). In some cases, this means seeking to increase profits and recover investments without trying to obtain a competitive edge by truly making the operations of the firm more sustainable. The use of practices which are not believable has, from the beginnings of the application of green marketing, left consumers feeling sceptical and confused. That scepticism demonstrates that green marketing goes far beyond changing one or two product attributes and the appearance of confusing (or even misleading) slogans on packaging (Ottman 1993). A study conducted by Teisl and Roe (2005) shows that the use of eco-labelling strategies directly influences perceived credibility and the trust placed in the products concerned, and that although there is a preference on the part of consumers for less environmentally-harmful products the wrong strategy can be a major hindrance for marketing them.

A fully 'green' strategy must entail incorporating environmental protection criteria into all the activities and attitudes of a firm (Polonsky and Rosenberger 2001): green marketing operations must involve all functional areas if they are to be effective (Getzner and Grabner-Kräuter 2004). That means tackling the green 
marketing function from a holistic viewpoint and bringing about a pro-environmental transformation in all activities throughout the value chain. In other words, it means introducing radical changes into how production systems are conceived and how products are marketed and consumed with a view to minimising their impact on the natural environment. This is therefore a concept of marketing that is far removed from the early ideas of merely meeting the needs of specific market segments of environmentally friendly consumers: it focuses rather on the need to redirect environmental responsibility in all functional areas of a business (Hutchinson 1996). Thus, even though many organisations see increasingly strict environmental regulations as a hindrance the more proactive among them see an opportunity to maintain a sustainable competitive edge (Porter and Van der Linde 1995, Sindhi and Kumar 2012).

Green marketing has been shown not to have developed in line with the expectations held 20 or 30 years ago, perhaps due to poor decision-making. However, an essential requirement for it is that society in general should be sufficiently prepared to make the relevant changes. Green marketing needs to operate in a society where sustainability has been taken on board by the public, has become a goal of the public authorities and is supported by fiscal, educational, industrial, legislative and other policies (Frame and Newton 2007), even if this view has not yet come to full maturity (Tadajewski and Brownlie 2008). That is why, in the words of Peattie and Crane (2005, p. 368): 'green marketing should not therefore be written off as a prophecy unfulfilled but recognised as one whose time has not yet come'.

\subsection{Proposed definition of green marketing as a holistic concept}

Confusion concerning the definition of this type of marketing is increased by the fact that it is known by various names. Apart from green marketing it is also referred to as eco-marketing, and the terms 'green', 'ecological', 'environmental' and 'sustainable' are sometimes used as synonyms (Peattie and Crane 2005, Caruana 2007, Durmaz and Zengin 2011, Szocs 2011).

Its purpose is to reduce the negative consequences for the environment of the operations of firms and their products, and thus contribute to profitability at those firms and to sustainable development.

It is therefore a general concept. Focussing on partial analyses would be a mistake: one can hardly speak of green advertising or of the eco-design of products outside the framework of a broader concept of pro-environmental action at firms. To do so would be to run the risk of being seen by consumers as seeking only greenwashing (Dobin 2009, Parguel et al. 2011). Factoring in environmental issues at strategic level enables them to be included in the marketing function, since there can be no green or eco-marketing unless there has first been a strategic reflection and the firm has provided itself with general tools for implementing overall environmental management (Juwaheer et al. 2012, Lu et al. 2015, Thakur and Aurora 2015, Vitell 2015).

Along these lines, Peattie and Charter (2003) see green marketing as 'the holistic management process responsible for identifying, anticipating and satisfying the 
requirements of customers and society, in a profitable and sustainable way'. Numerous other authors and definitions also stress that sustainability and environmental friendliness must become first-order concerns for firms (Szocs 2011).

However, the consumer's viewpoint must not be forgotten: focusing green marketing on the need to change production and management processes at organisations means associating it with sustainable management. The concept of green marketing also sees the environment not just as a factor that plays a more or less substantial role in the commercial strategies of firms but as one whose goal is to meet the needs of consumers. Accordingly, Durmaz and Zengin (2011) conclude that green marketing must pursue two objectives: to improve the quality of the environment and to satisfy consumers.

Nor should too narrow a view of green marketing be taken, focused excessively on purchasing or on the process of consumption. Such a view could lead to the idea that an environmental crisis caused by overconsumption can be solved by encouraging still more consumption in the form of green products (Peattie and Crane 2005).

We therefore propose the following definition of green marketing: a holistic management process at an organisation that seeks to minimise its impact on the environment and on society, taking into account the full product life cycle so as to offer value to consumers profitably and take account of their concern for the environment.

In other words, we feel that a complete definition of green marketing should cover the following elements:

Holistic management process: efforts to minimise negative impacts on the environment should cover the full life cycle of a product 'from cradle to cradle' (McDonnough and Braungart 2003). They need to be linked to the concept of corporate social responsibility.

Offer value to consumers: companies (and the same may be said of non-profit organisations) need to meet the needs of consumers profitably, taking into account in this case the increase in awareness of environmental issues in the past few decades. Green products often find themselves in complex, risky situations as regards competition, either because consumers cannot directly perceive the characteristics of the environmental offerings of an organisation or because such products are more expensive than conventional ones. For example, taking environmental externalities on board may increase product prices, so that the win-win philosophy usually proclaimed is not easy to implement in practice (Peattie and Crane 2005).

Use of the environmental variable as a distinguishing factor: green marketing seeks to use the environmental variable as a distinguishing factor to attract consumers who value a particular product for its better environmental performance. The environment factor can work in this way, but if the proper performance of conventional functions is ignored firms may fall into a short-sighted view of green marketing (Ottman, Stafford and Hartman 2006, Naderi and Strutton 2015). Underlying consumers' behaviour in regard to the environment there is a comparison between conventional and environmentally friendly offerings. The attractiveness of offerings with environmentally friendly attributes needs to be consolidated based on 
their helping to provide a level of satisfaction at least as high as that of the equivalent conventional products.

Thus, green marketing must be understood in the context of a social concept of the philosophy of marketing that combines aspects of social marketing (which can help by shifting attitudes towards support for environmental protection), a social orientation of corporate marketing and even elements of what is known as macromarketing and demarketing, as argued above.

\section{Conclusions}

This study analyses the role of green marketing by examining the relationship between marketing, consumption and the environment from a macro-marketing perspective. A brief review of the literature in this area suffices to evidence the need for green marketing to be seen as a holistic sub-discipline.

There is no denying that marketing is closely linked to the phenomenon of consumption as one of the main axes of the dominant social paradigm of our time, and that consumerism is one of the fundamental causes of what has become known as the environmental crisis. That is why the role that marketing can play in changing behaviour patterns with a view to preserving the environment is not easy to analyse, in that it goes far beyond merely changing certain product attributes.

Given the multifaceted, complex nature of the problem of the environment, green marketing must be seen as a holistic tool that covers the whole of the process of consumption. This means taking into account not just production but also the purchasing of products, their use, their disposal and the re-incorporation of waste into the production cycle.

In answer to the question posed in the title of this study, the ability of marketing to influence the environment positively may be called into doubt: some authors consider that marketing may be a useful tool for modifying the dominant social paradigm (without going beyond its limits), while others argue that marketing will always be subservient to a way of organising production and consumption that is not compatible with protecting the environment, and that a change of paradigm is required.

In any event, green marketing can be seen as a contradiction in terms when it is limited to a mere one-off, and greenwashing actions aimed mainly at increasing sales with the excuse of meeting demands based on environmental concerns. It must be acknowledged, however, that it has considerable potential as a tool for achieving the opposite of what it has done up to now, i.e. for de-linking happiness and well-being from consumerism and materialism and for fostering more responsible consumption and behaviour patterns which are less harmful to the environment.

It is important to point out that there is a need for more studies to analyse these complex relationships and broaden the focus of attention, so that an excessively narrow approach to green marketing does not become a hindrance to its development and its potential as an agent for change. Green marketing is not a fashion or a passing 
fad. It must also be understood that the conditions required for it to take off are not yet in place. Sustainability is not yet a priority social goal for public administrations or indeed for many members of general public.

Address:

Julen Izagirre-Olaizola

Department of Financial Economics II

University of the Basque Country (UPV/EHU)

Oñati Plaza 1

20018, Donostia, Spain

E-mail: julen.izaguirre@ehu.eus

Tel.: +34943015591

\section{References}

Barbarossa, Camilla, Suzanne C. Beckmann, Patrick De Pelsmacker, Ingrid Moons, and Wencke Gwozdz (2015) "A self-identity based model of electric car adoption intention: a cross cultural comparative study”. Journal of Environmental Psychology 42, 149-160.

Barbarossa, Camilla and Patrick De Pelsmacker (2016) "Positive and negative antecedents of purchasing eco-friendly products: a comparison between green and non-green consumers". Journal of Business Ethics 134, 2, 229-247.

Bauman, Zygmunt (2007) Consuming life. Cambridge: Polity.

Beck, Ulrich (1998) World risk society. Cambridge: Polity.

Bertalanffy, Ludwig V. (1968) General system theory: foundations, development, applications. New York: George Braziller.

Bonini, Sheila and Jeremy Oppenheim (2008) "Cultivating the green consumer". Stanford Social Innovation Review 6, 4, 56-61.

Brosius, Nina, Karen V. Fernandez, and Hélène Cherrier (2013) "Re-acquiring consumer waste: treasure in our trash?”. Journal of Public Policy and Marketing 32, 2, 286-301.

Calomarde, José V. (2000) Marketig ecológico. Madrid: Ediciones Pirámide.

Carrete, Lorena, Raquel Castaño, Félix Reto, Édgar Centeno, and Eva González (2012) "Green consumer behavior in an emerging economy: confusion, credibility, and compatibility". Journal of Consumer Marketing 29, 7, 470-481.

Carollo, Luca and Marco Guerci (2018) “'Activists in a suit': paradoxes and metaphors in sustainability managers' identity work". Journal of Business Ethics 148, 249-268.

Caruana, Robert (2007) “A sociological perspective of consumption morality”. Journal of Consumer Behaviour 6, 5, 287-304.

Chamorro, Antonio, Sergio Rubio, and Francisco J. Miranda (2009) "Characteristics of research on green marketing”. Business Strategy and the Environment 18, 4, 223-239.

Chatzidakis, Andreas and Michael S. W. Lee (2013) “Anti-consumption as the study of reasons against". Journal of Macromarketing 33, 3, 190-203.

Chen, Yu Shan and Ching-Hsun Chang (2013) "Greenwash and green trust: the mediation effects of green consumer confusion and green perceived risk". Journal of Business Ethics 114, 3, 489-500. 
Cherrier, Hélène (2010) “Custodian behavior: a material expression of anti-consumerism”. Consumption Markets and Culture 13, 3, 259-272.

Clark, John (1990) Renewing the Earth: the promise of social ecology. London: Green Print.

Connolly, John and Andrea Prothero (2003) "Sustainable consumption: consumption, consumers and the commodity discourse". Consumption, Markets and Culture 6, 4, 275-291.

Cronin, Joseph J., Jeffery S. Smith, Mark R. Gleim, Edward Ramírez and Jennifer D. Martínez (2011) "Green marketing strategies: an examination of stakeholders and the opportunities they present". Journal of the Academy of Marketing Sciences 39, 1, 158-174.

Dobin, Diana (2009) “Greenwashing harms entire movement”. Lodging Hospitality 65, 14, 42.

Donaldson, Thomas and Lee E. Preston (1995) "The stakeholder theory of the corporation: concepts, evidence and implications". Academy of Management Review 20, 1, 65-91.

Dunlap, Riley E. and Kent D. Van Liere (1986) "Commitment to the dominant social paradigm and concern for environmental quality”. Social Science Quarterly 65, 4, 1013-1028.

Durmaz, Yakup and Sevil Zengin (2011) “A theoretical approach to the concept of green marketing". Interdisciplinary Journal of Contemporary Research in Business 3, 2, 1808-1814.

Ertekin, Zenyep O. and Deniz Atik (2015) "Sustainable markets: motivating factors, barriers and remedies for mobilization of slow fashion". Journal of Macromarketing 35, 1, 53-69.

Estes, Richard J. (2010) "Toward sustainable development: from theory to praxis". In Nalini J. Negi and Rich Furman, eds. Trans-national social work practice. New York: Columbia University Press.

Frame, Bob and Bronwyn Newton (2007) "Promoting sustainability through social marketing: examples from New Zealand”. International Journal of Consumer Studies 31, 6, 571-581.

Ger, Güliz (1999) "Experiential meanings of consumption and sustainability in Turkey". Advances in Consumer Research 26, 276-279.

Ger, Güliz and Russell W. Belk (1995) "Cross-cultural differences in materialism”. Journal of Economic Psychology 17, 1, 55-77.

Getzner, Michael and Sonja Grabner-Kräuter (2004) "Consumer preferences and marketing strategies for 'green shares': specifics of the Austrian markets". The International Journal of Bank Marketing 22, 4, 260-278.

Global Footprint Network (2016) Working guidebooks to the national footprint accounts: 2016 edition. Oakland, CA: Global Footprint Network

Gollnhofer, Johanna F. (2017) "The legitimation of a sustainable practice through dialectical adaptation in the marketplace". Journal of Public Policy and Marketing 36, 1, 156-168.

Hahn, Tobias, Frank Figge, Jonatan Pinkse, and Lutz Preuss (2018) “A paradox perspective on corporate sustainability: descriptive, instrumental, and normative aspects". Journal of Business Ethics $148,1-14$.

Harvey, Brian and Anja Schaefer (2001) "Managing relationships with environmental stakeholders: a study of UK water and electricity utilities". Journal of Business Ethics 30, 3, 243-260.

Hutchinson, Colin (1996) "Integrating environmental policy with business strategy". Long Range Planning 29, 1, 11-23.

Juwaheer, Thanika D., Shamila Pudaruth, and Marie M. E. Noyaux (2012) "Analysing the impact of green marketing strategies on consumer purchasing patterns in Mauritius". World Journal of Entrepreneurship, Management and Sustainable Development 8, 1, 36-59.

Kang, Charles, Frank Germann, and Rajdeep Grewal (2016) "Washing away your sins? Corporate social responsibility, corporate social irresponsibility, and firm performance". Journal of Marketing 80, 2, 59-79. 
Kemper, Joya, Michael Hall, and Paul W. Ballantine (2019) "Marketing and sustainability: business as usual or changing worldviews?”. Sustainability 11, 3, 780.

Kilbourne, William E. (1995) “Green advertising: salvation or oxymoron?”. Journal of Advertising 24, $2,7-19$.

Kilbourne, William E. and Suzanne C. Beckmann (1998) "Review and critical assessment of research on marketing and the environment". Journal of Marketing Management 14, 513-532.

Kotler, Phillip (1971) "What consumerism means for marketers". Harvard Business Review 50, 3, $48-57$.

Lee, Mike, Dominique Roux, Hélène Cherrier, and Bernard Cova (2011) "Anticonsumption and consumer resistance: concepts, concerns, conflicts and convergence". European Journal of Marketing 45, 11-12, 1680-1687.

Linz, Manfred (2007) “Sobre suficiencia y vida buena”. In M. Linz, J. Riechmann, and Joaquín Sempere (2007) Vivir (bien) con menos. Barcelona: Icaria Editorial.

Lu, Long-Chuan, Hsiu-Hua Chang, and Alan Chang (2015) "Consumer personality and green buying intention: the mediate role of consumer ethical beliefs". Journal of Business Ethics 127, 1, 205-219.

Ludevid, Manuel (2000) La gestión ambiental de la empresa. Madrid: Ariel.

McDonnough, William and Michael Braungart (2003) "Cradle to cradle: remaking the way we make things". New York: Rodale Press.

Milbraith, Lester W. (1984) Environmentalists: vanguard for a new society. New York: State University of New York Press.

Moons, Ingrid and Patrick De Pelmacker (2012) "Emotions as determinants of electric car usage intention". Journal of Marketing Management 28, 3-4, 195-237.

Moravcikova, D., A. Krizanova, J. Kliestikova, and M. Rypakova (2017) "Green marketing as the source of the competitive advantage of the business". Sustainability 9, 12, 2218. DOI: https:// doi.org/10.3390/su9122218.

Naderi, Iman and David Strutton (2015) "I support sustainability but only when doing so reflects fabulously on me: can green narcissists be cultivated?". Journal of Macromarketing 35, 1, 70-83.

Nair, Sumesh R. and Victoria J. Little (2016) "Context, culture and green consumption: a new framework". Journal of International Consumer Marketing 28, 3, 169-184.

Nyilasy, Gergely, Harsha Gangadharbatla, and Angela Paladino (2014) "Perceived greenwashing: the interactive effects of green advertising and corporate environmental performance on consumer reactions". Journal of Business Ethics 125, 4, 693-707.

O'Shaughnessy, John and Nicholas J. O'Shaugnessy (2002) "Marketing, the consumer society and hedonism". European Journal of Marketing 36, 5-6, 524-547.

Ottman, Jacquelyn A. (1993) Green marketing: challenges and opportunities for the new marketing age. Chicago: NTC Business Books.

Ottman, Jacquelyn A., Edwin R. Stafford, and Cathy L. Hartman (2006) "Avoiding Green marketing myopia". Environment 48, 5, 22-36.

Parguel, Béatrice, Florence Benôit-Moreau, and Fabrice Larceneux (2011) "How sustainability ratings might deter 'greenwashing': a closer look ethical corporate communication". Journal of Business Ethics 102, 15, 15-28.

Peattie, Ken (1999) "Rethinking, marketing”. In Charter, Martin and Michael Jay Polonsky, eds. 
Greener marketing: a global perspective on greening marketing practice. Sheffield: Greenleaf Publishing.

Peattie, Ken and Martin Charter (2003) "Green marketing”. In Michael Baker and Susan Hart, eds. The marketing book. Oxford: Butterworth Heinemann.

Peattie, Ken and Andrew Crane (2005) "Green marketing: legend, myth, farce or prophesy?". Qualitative Market Research: An International Journal 8, 4, 357-370.

Peattie, Ken and Sue Peattie (2009) "Social marketing: a pathway to consumption reduction?". Journal of Business Research 62, 2, 260-268.

Pereira, María Teresa and Andrew Chatzidakis (2011) "Blame it on marketing: consumers' views on unsustainable consumption". International Journal of Consumer Studies 36, 6, 656-667.

Pickett-Baker, Josephine and Ritsuko Ozaki (2008) "Pro-environmental products: marketing influence on consumer purchasing decision". Journal of Consumer Marketing 25, 2, 281-293.

Polonsky, Michael Jay and Philip J. Rosenberger (2001) "Reevaluating green marketing: a strategic approach". Business Horizons, september-october, 21-30.

Porter, Michael E. and Claas Van der Linde (1995) "Green and competitive: ending the stalemate". Harvard Business Review 73, 5, 120-134.

Prothero, Andrea and James A. Fitchett (2000) "Greening capitalism: opportunities for a green commodity”. Journal of Macromarketing 20, 1, 46-55.

Prothero, Andrea, Pierre McDonagh, and Susan Dobscha (2010) "Is green the new black? Reflections on a green commodity discourse". Journal of Macromarketing 30, 2, 147-159.

Roberts, Paul (2005) The end of oil: the decline of the petroleum economy and the rise of a new energy order. London: Bloomsbury Publishing.

Saari, U., M. Fritz, S. Makinen, and R. Baumgartner (2018) "Designing green marketing across industries: a conceptual framework and implications for consumers and transdisciplinary research". I: Leal Filho W., ed. Handbook of sustainability science and research. (World Sustainability Series.) Basel: Springer International Publishing.

Santesmases, Miguel (2012) Marketing: conceptos y estrategias. Madrid: Pirámide.

Shankar, Avi, Julie Whittaker, and James A. Fitchett (2006) "Heaven knows i'm miserable now". Marketing Theory 6, 4, 485-505.

Soler, Cecilia (2012) "Conceptualizing sustainably produced food for promotional purposes: a sustainable marketing approach”. Sustainability 4, 3, 294-340.

Starik, Mark and Gordon P. Rands (1995) "Weaving integrated web: multilevel and multisystem perspectives on ecologically sustainable organizations". Academy of Management Review 20, 4, 908-935.

Szocs, Courtney R. (2011) "Green marketing: analysis and classification”. Journal of Consumer Research 34, 1, 256-263.

Tadajewski, Mark and Douglas Brownlie (2008) Critical marketing. contemporary issues in marketing. United Kingdom: John Wiley and Sons.

Teisl, Mario F. and Brian Roe (2005) "Evaluating the factors that impact the effectiveness of ecolabelling programmes". In S. Krarup and C. S. Russell, ed. Environment, information and consumer behaviour. United Kingdom: Edward Edgar Publishing.

Tencati, Antonio and Stefano Pogutz (2015) "Recognizing the limits: sustainable development, corporate sustainability and the need for innovative business paradigms". Sinergie. Italian Journal of Management 33, 96, 37-55. 
Thakur, Sonal and Rajinder Aurora (2015) "Consumer preferences change when it comes to green marketing". Journal of Recent Research Aspects 2, 2, 245-255.

Varey, Richard J. (2010) "Marketing means and ends for a sustainable society: a welfare agenda for transformative change". Journal of Macromarketing 30, 2, 112-126.

Vicente, María Azucena (2000) “Marketing ecológico”. In María Soledad Aguirre García, ed. Marketing en sectores especificos. Madrid: Pirámide.

Vitell, Scott J. (2015) "A case for consumer social responsibility (CnRS), including a selected review of consumer ethics/social responsibility research". Journal of Business Ethics 130, 4, 767-774.

Wackernagel, Mathis and William Rees (1996) Our ecological footprint: reducing human impact on the Earth. United States: New Society Publishers.

Yakobovitch, Nadav and Amir Grinstein (2016) "Materialism and the boomerang effect of descriptive norm demarketing: extension and remedy in an environmental context". Journal of Public Policy and Marketing 35, 1, 91-107. 